Article

\title{
Biological Treatment by Active Sludge with High Biomass Concentration at Laboratory Scale for Mixed Inflow of Sunflower Oil and Saccharose
}

\author{
Pedro Cisterna \\ Department of Civil and Environmental Engineering, University of Bío Bío, Concepción, Z.C. 378000, Chile; \\ pcisterna@ubiobio.cl; Tel.: +56-949-807-764
}

Received: 17 July 2017; Accepted: 25 September 2017; Published: 28 September 2017

\begin{abstract}
We studied and quantified the elimination of sunflower oil from a wastewater influent using a biological treatment by activated sludge. Estimation of the biodegraded material was obtained doing a mass balance, and we conducted a follow-up of the different operational parameters and design. We delivered information about the operation of a system for treatment by activated sludge fed with an influent with sunflower oil and saccharose. The influent was previously agitated before entering the effluent sludge in a lab-scale plant. The working range for oil concentration was 100 to $850 \mathrm{mg} / \mathrm{L}$ in the influent. Biodegradation was in the range of $60 \%$ to $51 \%$. The process works better with a high initial concentration of biomass $(7500 \mathrm{mg} / \mathrm{L})$ in order to absorb the impacts caused by the oil on the microorganisms. The lowest total suspended solids concentration was $4500 \mathrm{mg} / \mathrm{L}$. The elimination of sunflower oil in biodegradation and flotation was on the order of $90 \%$.
\end{abstract}

Keywords: biodegradation; fat; activated sludge

\section{Introduction}

Domestic wastewater and some types of industrial wastewater contain fats and oils in a considerable proportion. The fraction of lipids in urban wastewater is $30-40 \%$ of the chemical oxygen demand (COD), a test that measures organic matter [1].

The typical solution used for the elimination of fats and oils is based on physical and physico-chemical treatments, generating high volumes of fatty semisolid waste that is also highly undesirable from an environmental point of view. Considering the above mentioned, it is worth the effort to investigate an alternative biologically-based treatment for such types of waste.

In this laboratory-scale experiment, artificial wastewater containing oil and a substrate simulating residual water of urban or industrial origin, is biologically treated by activated sludge.

Degradation of sunflower oil was studied in an influent that also had saccharose. The influent is treated in an activated sludge plant designed to work with high concentrations of biomass. Initial biomass concentration (TSS) was $7500 \mathrm{mg} / \mathrm{L}$, in order to face the situation of a substrate of a slower biodegradation.

The behavior of lipids in active sludge processes is, in general, not well understood. The literature generally states that lipids and fatty acids can be removed by biological treatment, which eventually causes foam formation composed of filamentous bacteria and flocs that also inhibit microbial reproduction [2].

In general, flotation is used in the separation of solids from fluids or between immiscible fluids. There are three different types of flotation, the difference is based on how the air is introduced into the wastewater: by the use of air at atmospheric pressure or dissolved and induced via air [3].

Physical-chemical treatment is applied to wastewater with fats and oils highly emulsified and dispersed, and where the size of fat particles is less than 20 microns. When using a dissolved air 
flotation system to treat wastewater in the oil industry, the elimination efficiency is increased from $50 \%$ to $88 \%$ due to the addition of chemicals [4]. On the other hand, using electro-coagulation achieves high effectiveness through the destabilization of the emulsions, improving the removal of oils and fats [5].

As for the biodegradability of fats and oils, there is generic information classifying them as a slowly biodegradable substance. As for the degradation itself, bacteria initially saves these substances in their cytoplasm and later, through an enzymatic process, they perform hydrolysis to produce an assimilable substrate that can be biodegraded [6].

There are three types of reactions catalyzed by microbial enzymes: oxidatives, hydrolytic, and synthesis. The hydrolytic enzymes are used to hydrolyze insoluble complex compounds, such as fats and oils, on simple components that pass through the cellular membrane by diffusion. These enzymes (for instance oxidoreductases) act outside the cell wall [7].

Fats and oils are biodegraded by a wide range of microorganisms, however, the most common is an extracellular enzyme called lipases. This enzyme releases fatty acids, as a result of enzymatic action [8]. Fatty acids can be biodegraded by a wider range of microorganisms, including microorganisms that do not produce extracellular lipolytic enzymes [9].

Wastewater with high lipid concentration inhibits the activity of microorganisms in biological treatment systems, such as activated sludge and methane fermentation. To reduce such inhibitory effects, microorganisms capable of effectively degrading edible oils can be selected from different environmental sources [10].

Taking into account that the fat and oil biodegradation process is slow, they do not enhance the development and growth of bacterial colonies and, therefore, it is recommended to acclimatize the biomass to this type of substrate for a certain period of time, such that the biomass adapts and achieves the expected biodegradation efficiency. The adaptation to the new substrate is due to mutations or changes caused by environmental conditions and chemical or physical agents, which modify the cell DNA, giving it new characteristics, which allows the cell to degrade new substrates from those generated by biodegradation. Spontaneous mutations occur in one of $10^{6}$ cells; however, the molecule DNA is able to self-replicate [11].

The process of activated sludge has been used for wastewater treatment from industrial and urban sources for a century. The design of these plants is carried out mostly based on empirical evidence. Since the 1960s, a more rational solution for the design of activated sludge has been developed. The latter solution is based on the observation that if any urban or industrial wastewater is put through an aeration process for a sufficient period of time, the content of organic matter is reduced, creating, at the same time, a flocculent sludge [12].

The typical design parameter of the activated sludge treatment system is the mass load (ML). By definition, the mass load of the aeration tank is the relation between the daily feed mass of organic matter that gets into the aeration tank and the degrading biomass content inside the same tank [7].

There are many studies about the behavior of lipids in biological treatment assessing the disposal process [5]. Biodegradation of substances, slightly or not soluble in water, is one of the greatest problems in the use of biotechnology for the treatment of contaminated solid and liquid waste [13]. Microorganisms use a wide variety of organic compounds, like carbon as an energy source, for growth. When these substrates are not reachable due to low solubility, competition with other microorganisms, or other environmental factors, the use of biosurfactants is recommended to obtain a carbon source [14].

In a biological treatment where activated sludge is in use, the efficient contact of phases, water and oil, is very important and, therefore, a significant interfacial area is required to reduce mass transfer limitations. The interfacial area can be expanded by delivering energy to the system by means of mechanical stirring or an electric field. The increment of the interfacial surface between the aqueous phase and oily or fatty phases is often implemented by mechanical stirring [15].

Regarding the stirred aeration tank used to complete the mixing and the corresponding dispersion level, there are two important factors that largely determine the emulsion level: bubble size and 
distribution, and the fraction of the dispersed phase. The average bubble size is between $150 \mu \mathrm{m}$ and $250 \mu \mathrm{m}$ [16], which can be obtained by means of a suitable booster and fine bubble diffusers.

If there is a suitable enzyme concentration and an optimal interfacial area between the aqueous phase and the oily phase, the mass transfer is solved and it gives way to the hydrolysis stage [17].

This investigation studies and quantifies sunflower oil biodegradation using a biological treatment system based on activated sludge at the laboratory scale with a high initial concentration of biomass (7500 mg/L).

\section{Materials and Methods}

\subsection{The Choice of Sunflower Oil Is Explained Based in the Following Criteria}

- It is the most frequent oil used in Chile;

- It is well standardized; and

- It is a highly accessible product.

The chemical composition of sunflower oil is shown in Table 1.

Table 1. Fatty acids that make up sunflower oil and specific stereoanalysis [18]. Results in \% moles.

\begin{tabular}{ccccccc}
\hline Fat & Position & $\mathbf{1 6 : 0}$ & $\mathbf{1 8}$ & $\mathbf{1 8 : 1 ( 9 )}$ & $\mathbf{1 8 : 2 ( 9 , 1 2 )}$ & $\mathbf{1 8 : 3 ( 9 , 1 2 , 1 5 )}$ \\
\hline \multirow{3}{*}{ Sunflower oil girasol } & 1 & 10.6 & 3.3 & 16.6 & 69.5 & - \\
& 2 & 1.3 & 1.1 & 21.5 & 76.0 & - \\
& 3 & 9.7 & 9.2 & 27.6 & 53.5 & - \\
\hline
\end{tabular}

\subsection{Physico-Chemical Parameters and Analytical Methods}

- Chemical Oxygen Demand (COD)

The potassium dichromate method was used to evaluate COD levels. The method used is a variation of the standard method [19], however, it maintains the basis of it. The variation used has the advantage that it uses a significantly smaller sample and reagents. The sample is chemically oxidized through the action of potassium dichromate at $150{ }^{\circ} \mathrm{C}$ for two hours. Silver sulfate is used as a catalyst and mercury sulfate is used to avoid possible interferences with chloride. Afterwards, determination by spectrophotometry at $600 \mathrm{~nm}$ is performed. Equipment and instruments used to determine the various parameters to characterize the wastewater were used.

The following parameters with their corresponding methods were measured:

- Total Suspended Solids (TSS), Volatile Suspended Solids (VSS) and Sludge Volumetric Index (SVI)

TSS is determined by filtering a known volume of the sample on Whatman (Whatman plc, Maidstone, UK) $4.7 \mathrm{~cm}$ GF/C glass fiber filters and then drying it at $103-105^{\circ} \mathrm{C}$. The difference in weight of the filter before and after filtration is used to estimate the TSS, 209C method [20]. The Volatile Suspended Solids are determined by weight loss after calcination at $550{ }^{\circ} \mathrm{C}, 208 \mathrm{E}$ method [20]. For Sludge Volumetric Index, method 213E is used [20].

- Fats and Oils

When determining the fats and oils, the Gravimetric Assay Soxhlet method is used. This method quantifies substances with similar characteristics on the basis of their common solubility in an appropriate solvent, 213E method [20]. 


\subsection{Determination of Chemical Oxigen Demand (COD)-Substrate Relationships}

Samples composed by mixtures of water and substrates prepared at different concentrations, and their respective COD is estimated. This test is performed in order to produce a calibration curve and establish a ratio (substrate concentration/COD).

\subsection{Continuous Equipment}

In the current investigation, an activated sludge plant at the laboratory scale is used to conduct biodegradability tests in wastewater with oils and fats. To meet these objectives, experimental work is required, with such parameter information describing the process dynamics regarding the aeration and sedimentation tanks regarding fat and oil content of the wastewater. For this purpose, BIOCONTROL-MARK 2 equipment was used. The details of the equipment is shown in Figure 1.

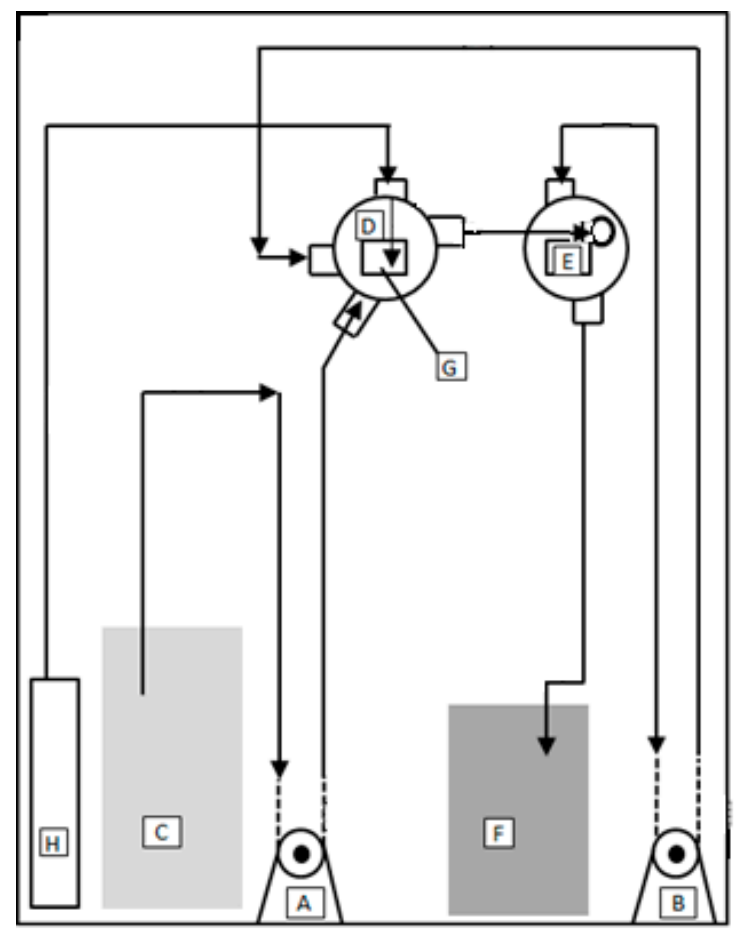

Description

A: Feed pump

B: Recirculation pump

C: Feed tank

D: Aeration tank

E: Sedimentation tank

F: Effluent collection tank

G: Oxygenation tank

H: Air flow meter

Figure 1. Experimental equipment diagram.

This experimental equipment consists essentially of the following parts:

\section{- Control Unit}

Composed of a main switch, an air cylinder, and is complemented with a flow meter and a flow regulation system. Additionally, a wastewater feed pump, complemented with a flow rate regulation system, a timer for intermittent operations, and an ON-OFF switch allowing sludge recycling from the sedimentation tank to the aeration tank.

\section{- Aeration Tank}

It consists of a transparent Plexiglas ${ }^{\circledR}$ (Vittadini Riferimenti, Milan, Italy) cylinder with a height of $38 \mathrm{~cm}$ and a diameter of $20 \mathrm{~cm}$, which has outlets at various heights associated with different volumes $(7,8,9$ and $10 \mathrm{~L})$. There are two separated inlets allowing the recirculation of sludge from the top. The influent to be treated is placed at the bottom. In addition, the system has two ceramic diffusers placed in the bottom in a way that they can disperse the air in tiny bubbles [21].

- Sedimentation Tank 
This consists of a transparent Plexiglas ${ }^{\circledR}$ (Vittadini Riferimenti, Milan, Italy) cylinder, where its lower part is cone-shaped to make sludge sedimentation and thickening easier.

The mixed liquor is fed from the aeration tank, which has, in its upper part, an outlet. This flow escapes by overflow, when it arrives to the sedimentation tank. The solid phase decantation gives a method to a downward flow. The decanted sludge is separated and recirculated at the bottom through a pump towards the aeration tank. Treated water also uses the overflow mechanism to be evacuated to the storage tank.

\subsection{Experimental Methodology}

\section{a. Feed Preparation}

The treatment system was fed initially with synthetic wastewater prepared in the laboratory according to the typical characteristics of strong urban wastewater [22]. This wastewater has an approximate BOD of $400 \mathrm{mg} / \mathrm{L}$, with the corresponding proportions of nitrogen and phosphorus, in a relation of BOD:N:P = 100:5:1. Approximately $400 \mathrm{mg}$ of saccharose, $20 \mathrm{mg}$ of phosphate hydrogen of potassium, and $100 \mathrm{mg}$ of ammonium chloride were added per liter of water. Measurements begin when sunflower oil is added, the concentration of this substrate gradually increases. Feed was prepared daily and nitrogen and phosphorus increased according to the organic input coming from fats and oils.

\section{b. Operating Modes}

The synthetic wastewater was poured into a storage pond of approximately $50 \mathrm{~L}$, in which a stirring unit has been installed to disperse the oil or fat. Through a peristaltic pump, controlled by the control unit, it drives the feed to the aeration tank. Oxygen feed and recirculation flow are controlled by the control unit. Process effluent is collected in a $30 \mathrm{~L}$ volume tank, where the samples are taken to be processed. The flow of synthetic wastewater is $25 \mathrm{~L} /$ day.

\section{Results}

\subsection{COD-Substrate Relationships}

From the experimental values, a straight line with a slope of 2.13 is obtained, as shown in Figure 2, from which it can be stated that this type of oil has a COD per gram, which is above of other organic substances [23]. The model obtained is: $\mathrm{Y}=2.1255 \mathrm{X}$.

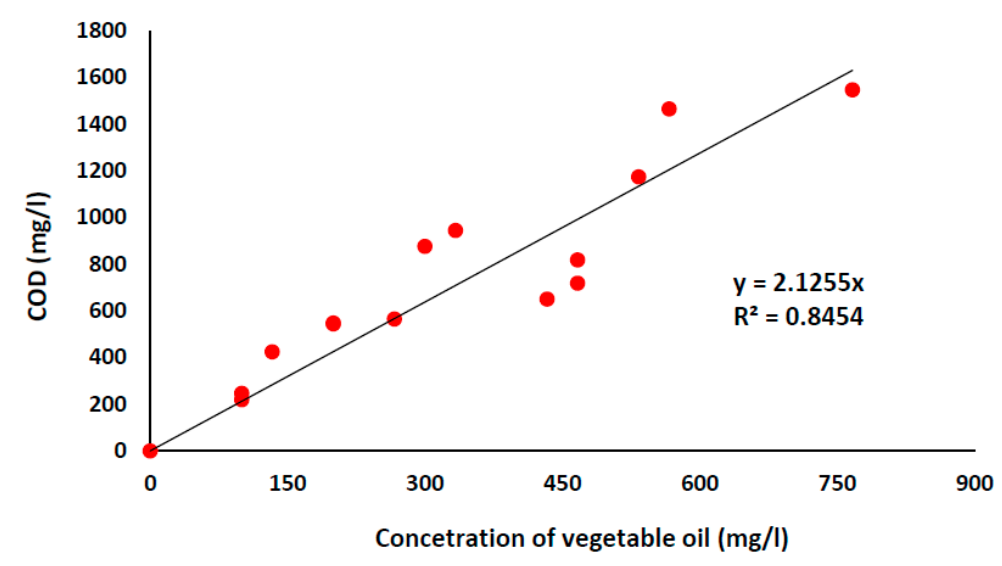

Figure 2. COD-sunflower oil relationship.

From the experimental values, a straight line with a slope of 1.17 is obtained, as shown in Figure 3 , from which it can be stated that the saccharose has a COD per gram, which is above of other organic substances [23]. The model obtained is: $\mathrm{Y}=1.1744 \mathrm{X}$. 


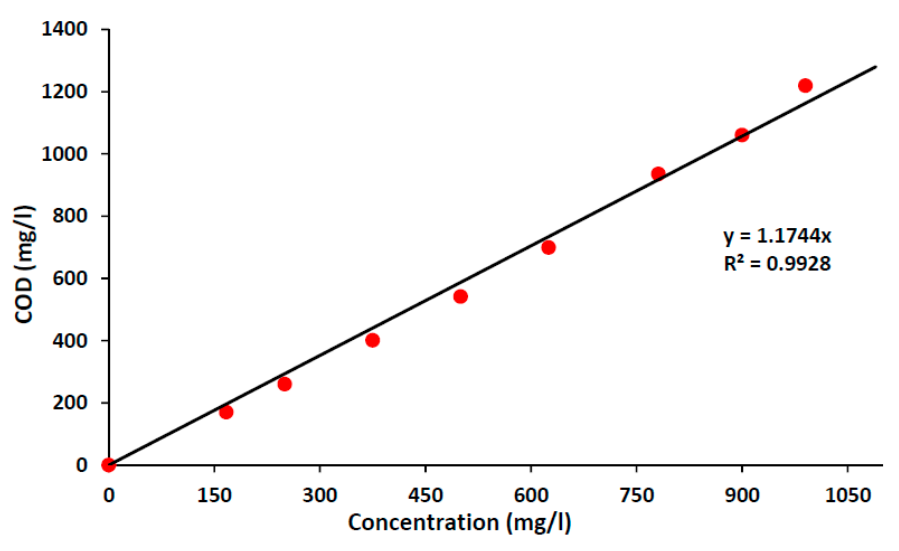

Figure 3. COD-saccharose relationship.

\subsection{Mass Balance}

In this experience, water and oil are mixed by mechanical stirring. Even though part of the added oil remains accumulated, it is important to determine the oil fraction which does not enter the aeration tank.

Biodegradability is estimated considering the oil that actually enters the aeration tank, which will correspond to the oil that is subject to a biological treatment process using activated sludge.

The influent has saccharose and sunflower oil. Saccharose concentration is constant and sunflower oil concentration is gradually increased. In this case, the initial biomass concentration present in the aerobic reactor is $7500 \mathrm{mg} / \mathrm{L}$.

As shown in Figure 4: F0, C0: Flow and concentration of oil entering the mixing tank. F1, C1: Flow and concentration of oil from the feed tank to the aeration tank. F2, C2: Flow and concentration of fat and oil exiting the aeration tank. F3, C3: Flow and concentration of fat and oil from the purified effluent. F4, C4: Flow and concentration of fat and oil in the recirculation flow. M1: Mass of oil contained in the mixing liquor of the aeration tank. M2: Mass of oil floating on top of the sedimentation tank and the mass of oil and fat at the bottom of sedimentation tank by adherence to the biomass.

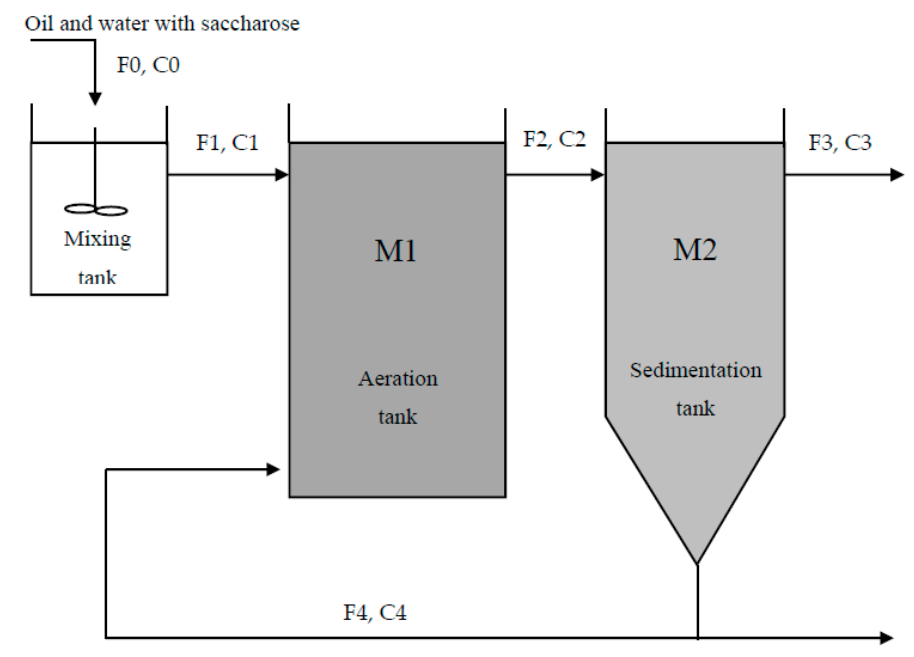

Figure 4. The plant process of activated sludge diagram.

Matter Balance: Determination of Biodegradability

From the matter balance, the mass of biodegraded sunflower oil is obtained, which is part of the influent to the system, as follows: 
For the aeration tank:

$$
\mathrm{dM}_{1} / \mathrm{dt}=\mathrm{F}_{1} \mathrm{C}_{1}-\mathrm{F}_{2} \mathrm{C}_{2}-\mathrm{r}_{\mathrm{A}} \mathrm{V}+\mathrm{F}_{4} \mathrm{C}_{4}
$$

For the secondary sedimentation tank:

$$
\mathrm{dM}_{2} / \mathrm{dt}=\mathrm{F}_{2} \mathrm{C}_{2}-\mathrm{F}_{3} \mathrm{C}_{3}-\mathrm{F}_{4} \mathrm{C}_{4}-\mathrm{F}_{6} \mathrm{C}_{6}
$$

It is pertinent to point out that, $\mathrm{F}_{6}=0$.

$\mathrm{M}_{1}$ : mass of oil and fat in the aeration tank.

$\mathrm{M}_{2}$ : mass of oil and fat in the sedimentation tank.

$\mathrm{V}$ : Volume of reactor.

$\mathrm{r}_{\mathrm{A}}$ : Disappearance speed of vegetable oil.

The balance for the whole system is:

$$
\mathrm{dM}_{1} / \mathrm{dt}+\mathrm{dM}_{2} / \mathrm{dt}=\mathrm{F}_{1} \mathrm{C}_{1}-\mathrm{F}_{3} \mathrm{C}_{3}-\mathrm{r}_{\mathrm{A}} \mathrm{V}
$$

From this expression, we have that the term $r_{A} V$, corresponding to vegetable oil disappearing by unit of time, is ultimately the oil purely degraded by the microorganisms, such that:

$$
\mathrm{r}_{\mathrm{A}} \mathrm{V}=\mathrm{F}_{1} \mathrm{C}_{1}-\mathrm{F}_{3} \mathrm{C}_{3}-\mathrm{dM}_{1} / \mathrm{dt}-\mathrm{dM}_{2} / \mathrm{dt}
$$

As it has been said, a significant part of the oil floats and, therefore, it is not biodegraded and goes directly into the secondary sedimentation tank, where it is accumulated. By reasons of technical feasibility, the enforcement of the matter balance must be performed holistically and not derivatively. Therefore, this accumulation effect due to floating is considered and measured, which is very important in order to measure the level of biodegradability corresponding to the influent that has oil.

When the matter balance is performed holistically, for a determined period of time, we have:

$$
\mathrm{M}_{1}+\mathrm{M}_{2}=\mathrm{F}_{1} \mathrm{C}_{1} \mathrm{Dt}-\mathrm{F}_{3} \mathrm{C}_{3} \mathrm{Dt}-\mathrm{r}_{\mathrm{A}} \mathrm{Dt}
$$

where $\mathrm{Dt}$ is the period of time, (one day).

Then, if a subscript is used to characterize the corresponding day, we have:

For day 1:

$$
\mathrm{M}_{11}+\mathrm{M}_{21}=\mathrm{F}_{11} \mathrm{C}_{11} \mathrm{Dt}-\mathrm{F}_{31} \mathrm{C}_{31} \mathrm{Dt}-\mathrm{Vr}_{\mathrm{A}} \mathrm{Dt}
$$

For day 2:

$$
\mathrm{M}_{12}+\mathrm{M}_{22}=\mathrm{F}_{12} \mathrm{C}_{12} \mathrm{dt}-\mathrm{F}_{32} \mathrm{C}_{32} \mathrm{Dt}-\mathrm{r}_{\mathrm{A}} \mathrm{VDt}
$$

For day $n$ :

$$
\mathrm{M}_{1 \mathrm{n}}+\mathrm{M}_{2 \mathrm{n}}=\mathrm{F}_{1 \mathrm{n}} \mathrm{C}_{1 \mathrm{n}} \mathrm{Dt}-\mathrm{F}_{3 \mathrm{n}} \mathrm{C}_{3 \mathrm{n}} \mathrm{Dt}-\mathrm{r}_{\mathrm{A}} \mathrm{VDt}
$$

the mass balance for a determined amount of days operating:

$$
\Sigma\left(\mathrm{M}_{1 \mathrm{i}}+\mathrm{M}_{2 \mathrm{i}}\right)=\mathrm{F}_{1 \mathrm{i}} \mathrm{Dt} \Sigma\left(\mathrm{C}_{1 \mathrm{i}}\right)-\mathrm{F}_{3 \mathrm{i}} \mathrm{Dt} \Sigma\left(\mathrm{C}_{3 \mathrm{i}}\right)-\mathrm{r}_{\mathrm{A}} \mathrm{VDt}
$$

Therefore, the expected biodegraded oil can be estimated by:

$$
\mathrm{F}_{1 \mathrm{i}} \mathrm{Dt} \Sigma\left(\mathrm{C}_{1 \mathrm{i}}\right)-\mathrm{F}_{3 \mathrm{i}} \mathrm{Dt} \Sigma\left(\mathrm{C}_{3 \mathrm{i}}\right)-\Sigma\left(\mathrm{M}_{1 \mathrm{i}}+\mathrm{M}_{2 \mathrm{i}}\right)=\mathrm{r}_{\mathrm{A}} \mathrm{VDt}
$$

Then biodegradability is:

$$
\begin{gathered}
\mathrm{D}=\mathrm{r}_{\mathrm{A}} \operatorname{VDt} / \mathrm{F}_{1 \mathrm{i}} \operatorname{Dt} \Sigma\left(\mathrm{C}_{1 \mathrm{i}}\right) \\
\mathrm{D}=\left\{\mathrm{F}_{1 \mathrm{i}} \operatorname{Dt} \Sigma\left(\mathrm{C}_{1 \mathrm{i}}\right)-\mathrm{F}_{3 \mathrm{i}} \operatorname{Dt} \Sigma\left(\mathrm{C}_{3 \mathrm{i}}\right)-\Sigma\left(\mathrm{M}_{1 \mathrm{i}}+\mathrm{M}_{2 \mathrm{i}}\right)\right\} / \mathrm{F}_{1} \operatorname{Dt} \Sigma\left(\mathrm{C}_{1 \mathrm{i}}\right)
\end{gathered}
$$




\subsection{Experimental Protocol of Matter Balance of the Activated Sludge Plant}

In this protocol an experimental method to conduct a thorough and accurate balance of fat and oil matter is proposed. From the process diagram, the streams of input and output are defined and measured both in flow and concentration.

Feed flow and concentration of fat and oil $\left(\mathrm{F}_{1}, \mathrm{C}_{1}\right)$ are known and set according to the experimental conditions.

$\mathrm{F}_{2}, \mathrm{C}_{2}$ : It is not significant for the matter balance.

$\mathrm{F}_{3}, \mathrm{C}_{3}$ : This flow is equal to the input flow and, therefore, it is given by the predetermined conditions for the experiment, and C3 concentration is obtained by Soxhlet method.

$\mathrm{F}_{4}, \mathrm{C}_{4}$ : It is not significant for the matter balance.

$\mathrm{M}_{1}$ : Oil concentration in mixed liquor measured by Soxhlet using a sample of $250 \mathrm{~mL}$. The concentration is calculated for the total volume of mixed liquor.

$\mathrm{M}_{2}$ : In this case, sunflower oil mass accumulated in the sedimentation tank in a determined period of time must be estimated, for which it is necessary to remove, dry, and weigh the supernatant oil.

This task was performed by implementing a drainage in the secondary sedimentation tank discharging to an auxiliary tank, and collecting the corresponding part of oil in another container. After this, water evaporation is performed in a water bath and the separated oil is weighed to determine the oil mass accumulated in a given period of time.

$\mathrm{M}_{21}$ : This is determined by Soxhlet extraction of oil accumulated in the biomass of the sedimentation tank.

\subsection{Matter Balance Results}

The empirical results of the mass balance is shown in Table 2.

Table 2. Matter balance of activated sludge with stirring and the increase of the initial biomass.

\begin{tabular}{ccccccc}
\hline $\begin{array}{c}\text { Period of Operation of } \\
\text { the Mass Balance (day) }\end{array}$ & $\begin{array}{c}\text { Fed Oil } \\
\text { Mass (g) }\end{array}$ & $\begin{array}{c}\text { Retained } \\
\text { Oil Mass (g) }\end{array}$ & $\begin{array}{c}\text { Accumulated } \\
\text { Oil Mass (g) }\end{array}$ & $\begin{array}{c}\text { Oil Mass in } \\
\text { Effluent (g) }\end{array}$ & $\begin{array}{c}\text { Biodegraded } \\
\text { Oil Mass (g) }\end{array}$ & $\begin{array}{c}\text { Biodegradation } \\
\text { Efficiency (\%) }\end{array}$ \\
\hline $1-8$ & 24 & 2 & 4 & 4.9 & 13.1 & 60 \\
$9-15$ & 48 & 5 & 13.5 & 6 & 23.5 & 54.6 \\
$16-22$ & 94 & 9 & 38 & 5.5 & 43.5 & 51 \\
\hline
\end{tabular}

\subsection{System Behavior and Operating Parameters}

\subsubsection{COD Removal and Mass Loading}

Figure 5 shows the elimination of COD and its relationship with the mass loading. As a design parameter of the active sludge, it is verified that the biodegradation of the oils and fats decreases with the increase of the mass load. This increase is given by the higher load of fats and oils, which is the substrate of slower biodegradation, and the value of this parameter indicates the accumulation of fats and oils. On the other hand these fats and oils are accumulated in the ponds of the system, therefore, they do not affect the efficiency of the elimination of fats and oils since they do not leave by the effluent. 


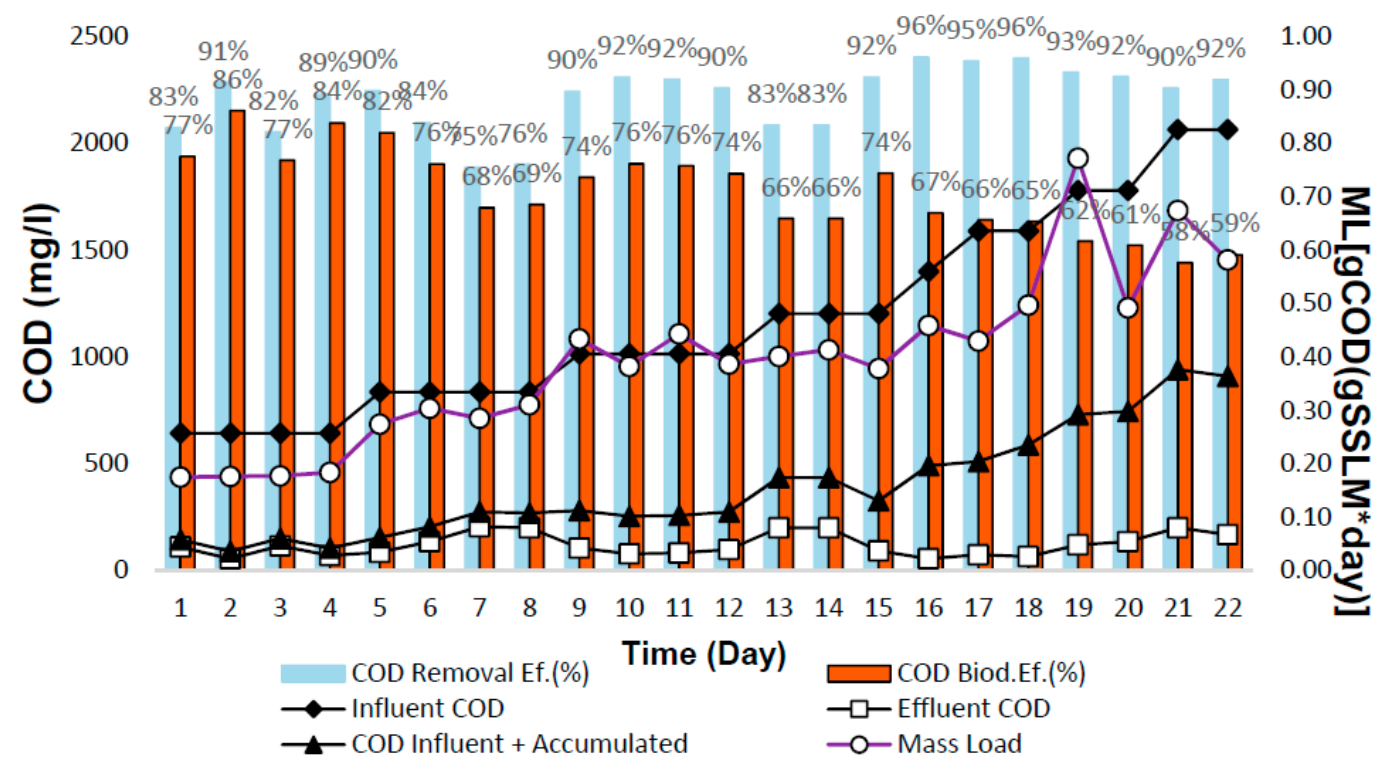

Figure 5. Graphic of the evolution of the removal and biodegradation of COD in the mass load.

\subsubsection{Behavior of Biomass}

Figure 6 shows the behavior of biomass through total suspended solids. The trend shows a decrease in the concentration of solids as oil is added to the system, although the process is reversed from the ninth day, which is explained by the acclimation of the microorganism to the oil. The high concentration of the initial biomass, $7500 \mathrm{mg} / \mathrm{L}$, allows a resistance to the decline in biomass caused by the fed influent. In fact, the lowest concentration of total suspended solids also corresponds to a high concentration, $4500 \mathrm{mg} / \mathrm{L}$. It is observed that the presence in the influent substrates causes an increase of the SVI of a value of $60 \mathrm{~mL} / \mathrm{g}$, to values that exceed $100 \mathrm{~mL} / \mathrm{g}$, then are stabilized at an average of $85 \mathrm{~mL} / \mathrm{g}$. It is remarkable that, despite the increase experienced by the SVI, the achieved values are within a suitable range, indicating proper biomass sedimentation in the activated sludge.

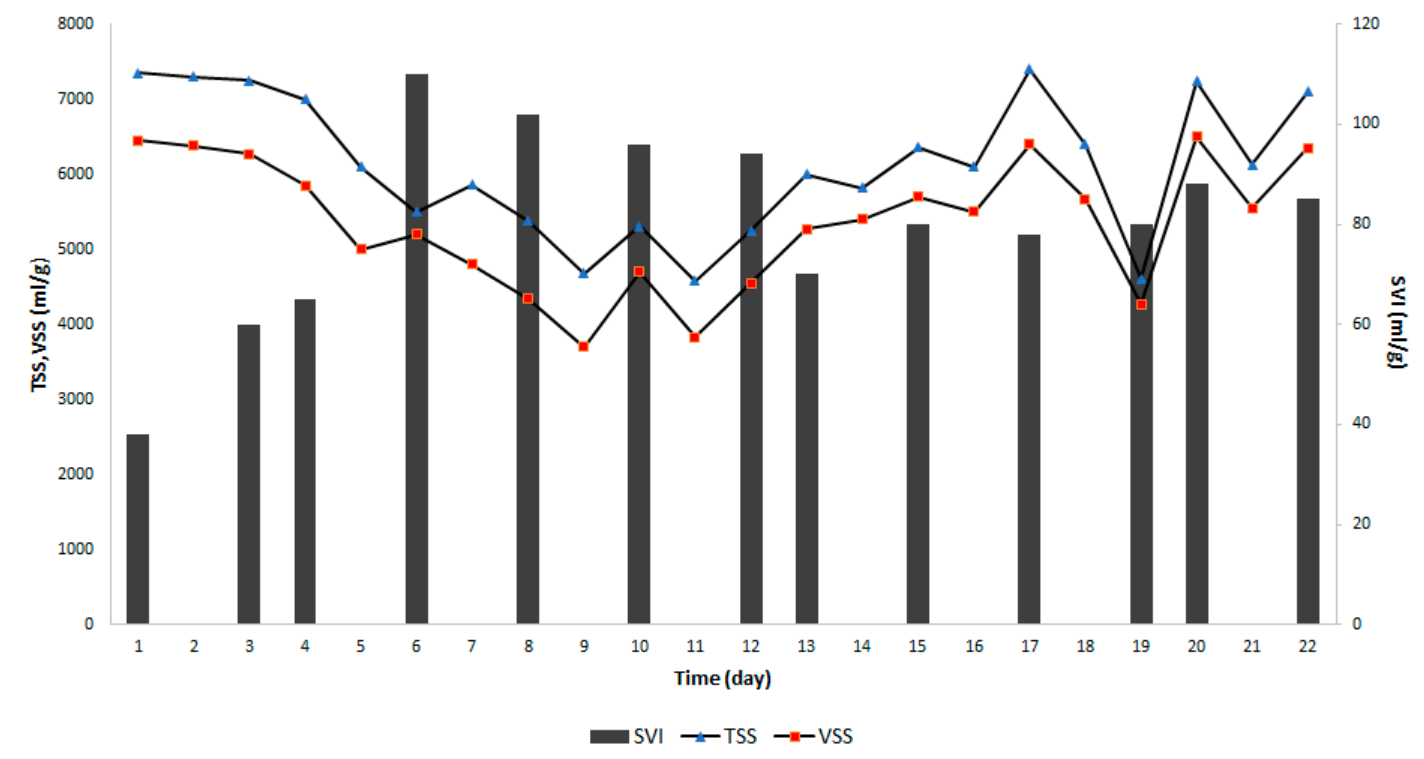

Figure 6. Graphic of the evolution of mass and SVL. 


\subsubsection{Sunflower Oil Removal and Biodegradation Efficiency}

It can be noticed that the concentration of grease and oil in the effluent is independent from the concentration of the influent containing sunflower oil. The latter is because the oil is not biodegraded and it is accumulated in the aeration tank and in the secondary sedimentation tank, as is shown in Figure 7 . Therefore, oil is removed by flotation. The elimination of sunflower oil by biodegradation and flotation reaches $90 \%$.

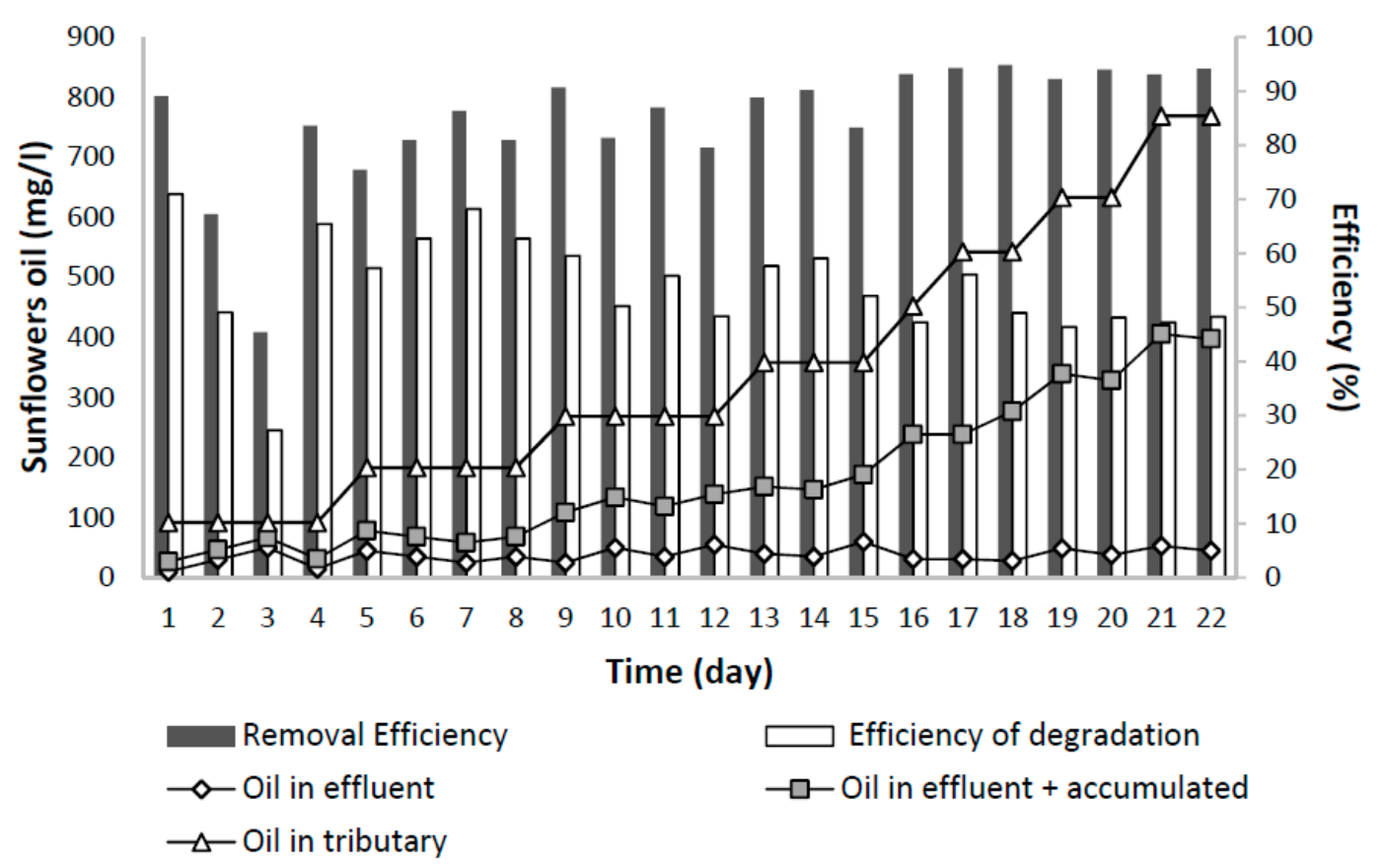

Figure 7. Graphic of the evolution of oil in the influent and effluent, mixed feed, biomass increase, removal efficiency, and biodegradation.

The low solubility of the sunflower oil in the aqueous phase also affects biodegradation, which is mitigated by the emulsification in small drops that create a kind of pseudo-solution corresponding to oil that is feasibly treated biologically.

Another biodegradation limiting factor is the amount of biomass available. In this experience, the oil mass was progressively increased and, therefore, the ratio of biomass oil and organic matter is decreasing. This is reflected by the increase of the mass load, as shown in Figure 5.

In experiments performed to characterize the transformation of lipids in activated sludge under aerobic conditions, the results showed that the total lipid content in the effluent could not be reduced under $300 \mathrm{mg} / \mathrm{L}$ when initial content of $2000 \mathrm{mg} / \mathrm{L}$ is used [5]. In this experience, despite the presence of an easily biodegradable substrate, such as saccharose, biodegradation reached in excess of $51 \%$, as shown in Figure 7.

\section{Discussion}

The biodegradation of oils and greases incorporates carbon to the ecological chains through the carbon cycle, which is the most sustainable option.

From the results, a significant level of biodegradation of sunflower oil exceeding $53 \%$ is verified. When analyzing this value, the competence of substrates must be considered, since in this case microorganisms have both saccharose and oil as carbon sources, and considering that saccharose is a substrate of easier biodegradation; they are developed with higher biodegradation rates than those species that are compatible with this kind of substrate. 
The oil biodegradability level is approximately 53\%, on average. This result confirms that, in a significant proportion, oil and fat can be removed from an influent by biodegradation mechanisms of the activated sludge process.

In experiences carried out in a batch reactor with a saccharose and sunflower oil mix, the reached values of biodegradation are on the order of $63-67 \%$ for the biomass that, before the experiment, was not subjected to the mix with sunflower oil [24] and, in this case, a continued system of activated sludge, the values go from $51 \%$ to $60 \%$, as they have some similarities.

The experience of an activated sludge system working with a biomass concentration within the normal rank (3000-4000 mg/L) shows a significant development of bulking from $120 \mathrm{~mL} / \mathrm{g}$ to $300 \mathrm{~mL} / \mathrm{g}$, approximately [25], and this biomass-reinforced system decreases bulking obtaining an SVI that is between $40 \mathrm{~mL} / \mathrm{g}$ to $115 \mathrm{~mL} / \mathrm{g}$, which shows a drastic difference.

On the other hand, laboratory studies for commercial supplements, multi-species bioaugmentation found removal values of fat and oil from $37 \%$ to $62 \%$ [26]. This result has some similarities with the effect of sludge acclimatization, which is also of a biological nature.

In the results there is an important percentage of sunflower oil that is not biodegraded; this is due to the lack of solubility of the substrate which originates as a biphasic system which is also increased by the oil tendency to float on water, especially when there is an air flow from the bottom. This means that an important part of the oil does not contact the biomass, violating an essential and basic condition for substrate biodegradation and, therefore, it goes from the feed tank to the secondary sedimentation tank where it is accumulated.

Regarding to the organic matter removal (saccharose and vegetable oil) (Figure 5), if the quality of the effluent resulting from the treatment of activated sludge is considered, optimal levels of performance are achieved, because there is a removal level of COD that is above $90 \%$, which would correspond to the COD being biodegraded, and also to removal by physical processes, such as oil floatation. For aerobic biological treatment, there are experiences in plants at full scale. An evaluation of 55 treatment plants of municipal water in the United States verified that fat and oil concentration in the influent had an average value under $80 \mathrm{mg} / \mathrm{L}$ and a BOD of $300 \mathrm{mg} / \mathrm{L}$, and the effluent obtained had a fat and oil concentration under $10 \mathrm{mg} / \mathrm{L}$ and a BOD under $40 \mathrm{mg} / \mathrm{L}$ to the level of effluent. It also can be observed that the fat and oil removal does not show a seasonal variation [27].

From Figure 5 it can be observed the efficiency of COD removal is over $80 \%$ and it does not depend on the mass load applied, which is explained by the fact that part of the removed oil is by physical mechanisms of separation. On the other hand, biodegradation decreases substantially when mass load increases. There are adequate removal levels when it is worked on a range of a conventional regime, but not for high rate ranges.

Therefore, the corresponding value to the COD disposal is higher than the one corresponding to the COD biodegradation because, in the first one, the accumulated oil in the aeration and sedimentation tank is not considered, mainly, which is the COD which is not biodegraded. This is necessary to perform a matter balance of the system so as to allow the more accurate measurement of the organic matter that has actually been biodegraded by the activated sludge.

In the application of biological treatment by activated sludge to the derived effluents from the olive oil industry, the treatment of green wastewater of olive oil-activated sludge was used and the results obtained show that this alternative of treatment is efficient, reaching levels of COD disposal of $75-85 \%$, with a COD of input between 1000 to $1500 \mathrm{mg} / \mathrm{L}$, due mainly to ethanol disposal and fatty acids.

The increase of hydraulic retention time and the temperature improved the sludge removal. Thus, the effluent systematically reached a concentration of 200 to $300 \mathrm{mg} / \mathrm{L}$ [28].

These results are very similar to those obtained by other researchers for biodegradation of olive oil in a batch-activated sludge system using both acclimated and non-acclimated sludge. For non-acclimated sludge, levels of biodegradability obtained between day 1 and day 4 were $6 \%$ to $68 \%$, while for acclimated sludge, results vary from day 2 to day 5 by $58 \%$ and 95\% [29]. 
The values of biodegradation of oil and fat obtained between $69 \%$ and $75 \%$, and are similar to those of an aerobic biodegradation experiment that removes fats and oils from the dairy industry, which uses as biomass a mixture of isolated and selected native bacteria, which reached $72 \%$ efficiency of biodegradation [30]. The biodegradation of oils and greases incorporates the carbon of these substrates to the ecological chains and the carbon cycle, from the ecosystem point of view, is the most sustainable option.

\section{Conclusions}

- Sunflower oil is biodegradable and it is reached a percentage of biodegradation above $51 \%$ for a wide range of concentrations of these kinds of substrates in the influent, despite the competitive presence of saccharose.

- The removed oil in the process of wastewater treatment is through floating and biodegradation mechanisms. The elimination of sunflower oil sustained in biodegradation and flotation reaches $90 \%$.

- It is concluded that it is pertinent to add superficial scavengers to the sedimentation tank that eliminate the floating oil.

- Biomass has a great capacity to adapt to an oil substrate and does not affect sedimentation.

Conflicts of Interest: The author declares no conflict of interest.

\section{References}

1. Dueholm, T.E.; Andreasen, K.H.; Nielsen, P.H. Transformation of lipids in activated sludge. Water Sci. Technol. 2001, 43, 165-172. [PubMed]

2. Chipasa, K.B.; Medrzycka, K. Behavior of lipids in biological wastewater treatment processes. J. Ind. Microbiol. Biotechnol. 2006, 33, 635-645. [CrossRef] [PubMed]

3. Sainz, J. Separación de aceites de efluentes industriales. Chem. Eng. 2004, 409, 93-99. (In Spanish)

4. De Turris, A.; Yabroudi, S.C.; Valbuena, B.; Cárdenas, C.; Herrera, L.; Rojas, C. Tratamiento de aguas de producción por flotación con aire disuelto. Interciencia 2011, 36, 211-218.

5. Chipasa, K.B.; Medrzycka, K. Characterization of the fate of lipids in activated sludge. J. Environ. Sci. 2008, 20, 536-542. [CrossRef]

6. Ronzano, E.; Dapena, J. Tratamiento Biológico De Las Aguas Residuales, 2nd ed.; Diaz de Santos: Madrid, Spain, 2002.

7. Rittmann, B.; McCarty, P. Biotecnología del Medio Ambiente; McGraw-Hill: Madrid, Spain, 2001.

8. Kurashige, J.; Matsuzaki, N.; Makabe, K. Modifications of fats and oils by lipases. J. Dispers. Sci. Technol. 1989, 10, 531-559. [CrossRef]

9. Ratledge, C. Microbial oxidations of fatty alcohols and fatty acids. J. Chem. Technol. Biotechnol. 1992, 55, 399-400. [CrossRef]

10. Sugimori, D.; Utsue, T. A study of the efficiency of edible oils degraded in alkaline conditions by Pseudomonas aeruginosa SS-219 and Acinetobacter sp. SS-192 bacteria isolated from Japanese soil. J. Microbiol. Biotechnol. 2012, 28, 841-848. [CrossRef] [PubMed]

11. Bitton, G. Wastewater Microbiology; John Wiley \& Sons: New York, NY, USA, 1994.

12. Ramalho, R.S. Tratamiento de Aguas Residuales, 2nd ed.; Reverte Ed.: Saint-Armand, QC, Canada, 2003.

13. Volkering, F.; Breure, A.M.; Van Andel, J.G. Effect of micro-organisms on the bioavailability and biodegradation of crystalline naphthalene. Appl. Microbiol. Biotechnol. 1993, 40, 535-540. [CrossRef]

14. Jiménez, D.; Medina, S.A.; Gracida, J.N. Propiedades, aplicaciones y producción de biotensoactivos. Int. J. Environ. Pollut. 2010, 26, 65-84.

15. Weatherley, L.R.; Rooney, D.W.; Niekerk, M.V. Clean synthesis of fatty acids in an intensive Lipase-Catalysed Bioreactor. J. Chem. Technol. Biotechnol. 1997, 68, 437-441. [CrossRef]

16. Tsouris, C.; Neal, S.H.; Shah, V.M.; Spurrier, M.A.; Y Lee, M.K. Comparison of liquid-liquid dispersions formed by a stirred tank and elestrostatic spraying. Chem. Eng. Commun. 1997, 160, 175-197. [CrossRef] 
17. Albasi, C.; Riba, J.P.; Sokolovska, O.; Bales, V. Enzimatic hydrolysis of sunflower oil, characterisation of interface. J. Chem. Technol. Biotechnol. 1997, 69, 329-336. [CrossRef]

18. Belitz, H.D.; Grosch, W. Química De Los Alimentos, 3rd ed.; Acribia, S.A., Ed.; Acribia Editorial: Zaragoza, Spain, 2009.

19. Crespi, M.; Huertas, J.A. Determinación simplificada de la demanda química de oxígeno por el método del dicromato. Water Technol. 1984, 13, 35-40.

20. APHA-AWWA-WPFC. Métodos Normalizados Para el Análisis de Agua Potable y Aguas Residuales; Diaz de Santos: Madrid, Spain, 1992.

21. Vittadini, G. Catálogo de Información de Equipamiento de Biocontrol; Vittadini Riferiment: Milan, Italy, 1991.

22. Eddy, M. Wastewater Engineering, Treatment and Reuse, 4th ed.; McGraw-Hill: Madrid, Spain, 2002.

23. Henze, M.; Harremoes, P.; Jansen, J.C.; Arvin, E. Wastewater Treatment, Biological and Chemical Processes; Springer: Berlin, Germany, 1995.

24. Cisterna, P.; Gutiérrez, A.; Sastre, H. Impact of previous acclimatization of biomass and alternative substrates in sunflower oil biodegradation. Dyna 2015, 82, 56-61. [CrossRef]

25. Cisterna, P.; Gutierrez, A.; Sastre, H. Biodegradación de aceite girasol con presencia de sacarosa mediante lodos activos a escala de laboratorio. Interciencia 2015, 40, 684-689.

26. Brooksbank, A.M.; Latchford, J.W.; Mudge, S.M. Degradation and modification of fats, oils and grease by commercial microbial supplements. J. Microbiol. Biotechnol. 2007, 23, 977-985. [CrossRef]

27. Young, J.C. Removal of grease and oil by biological treatment processes. J. Water Pollut. Control Fed. 1979, 51, 2071-2087. [PubMed]

28. Brenes, M.; Garcia, P.; Romero, C.; Garrido, A. Treatment of green table olive wastewater by activated-sludge process. J. Chem. Technol. Biotechnol. 2000, 75, 459-463. [CrossRef]

29. Wakelin, N.G.; Forster, C.F. An investigation into microbial removal of fats, oils and greases. Bioresour. Technol. 1997, 59, 37-43. [CrossRef]

30. Loperena, L.; Ferrari, M.D.; Díaz, A.L.; Guzmán, I.; Pérez, L.V.; Carvallo, F.; Travers, D.; Menes, R.J.; Lareo, C. Isolation and selection of native microorganisms for the aerobic treatment of simulated dairy wastewaters. Bioresour. Technol. 2009, 100, 1762-1766. [CrossRef] [PubMed] 